\title{
Housing renovation and energy systems: the need for social learning
}

Wiktoria Glad

The self-archived postprint version of this journal article is available at Linköping University Institutional Repository (DiVA):

http:/ / urn.kb.se/ resolve?urn=urn:nbn:se:liu:diva- 79113

N.B.: When citing this work, cite the original publication.

Glad, W., (2012), Housing renovation and energy systems: the need for social learning, Building Research \& Information, 40(3), 274-289. https:/ / doi.org/ 10.1080/ 09613218.2012.690955

Original publication available at:

https:/ / doi.org/ 10.1080/09613218.2012.690955

Copyright: Routledge

http:// www.routledge.com/ 


\title{
Housing renovation and energy systems: the need for social learning
}

\author{
Wiktoria Glad \\ Department of Thematic Studies, Tema Technology and Social Change, Linköping University, \\ 58183 Linköping, Sweden \\ E-mail: wiktoria.glad@liu.se
}




\begin{abstract}
Installing new energy systems in housing is claimed to be a way to meet national and international goals for reduced greenhouse gas (GHG) emissions. A socio-technical approach, based on social learning theory, is used to examine the energy systems of a large Swedish housing project 10 years after its renovation. A significant retrofitting measure was the introduction of metering. Important lessons are identified regarding relationships between tenants, professionals, and technical systems. The inappropriate assumptions underpinning the renovation about inhabitants' capabilities and demographics meant that the dwellings were not optimally refurbished to meet user requirements, particularly in regard to the choice of technologies and inhabitants' interface with them. Many of the installations are hidden from tenants and difficult for inhabitants to discover, explore and use. Occupants did not use the technologies (smart meters, thermostats, etc) as intended which lowered performance and also increased occupants' dissatisfaction. This was also evident in the high levels of support needed by the inhabitants. Social learning processes are vital for the success of demand reduction strategies. Any demand reduction approach must consider people, by investing in the social processes and the required learning for interfacing with technology, not merely the 'smart' technology itself.
\end{abstract}

Keywords: Energy demand, housing, smart metering, socio-technical systems, social learning, inhabitant behaviour, post-occupancy evaluation, low-carbon society 


\section{Introduction}

In international climate change debate, the building sector has been presented as an important change agent for reducing GHG emissions. Occupant use of buildings and technology, though claimed to have great potential for reducing GHG emissions, has been little researched (Levine and Ürge-Vorsatz, 2007; Stevenson and Leaman, 2010). It is important to examine and make sense of end user energy consumption. A Swedish government official report (SOU, 2008:25) identified an economically viable potential for $15 \%$ greater efficiency of electricity use and $28 \%$ greater efficiency of district heating use by the year 2016 .

However, there is usually a gap between the potential for improved energy efficiency and the actual achievement. Energy efficiency goals are rarely met, at least not in Swedish cases (Green, 2006). How can this gap be understood? The answer to this question could partly reside in how buildings are actually used. This paper focuses on energy issues concerning the use of buildings designed to meet high energy efficiency standards.

Since the mid 1990s, research in the energy field has acknowledged the social and socio-technical aspects of energy use (Lutzenhiser, 1993; Wilhite et al., 1996; Wilhite et al., 2000; Kollmuss and Agyeman, 2002; Shove, 2003; Moloney et al., 2010; Crosbie and Baker, 2010). The current paper has found inspiration in this research into energy use practices. However, its focus is on the relationship between inhabitants and professionals as parts of the socio-technical system of energy use in blocks of flats. The overarching aim of the present research, which uses qualitative case study methodology, is to improve the understanding of cross-professional and tenant practices in the use of a newly installed energy system in apartment blocks. The main objective is to explore the end use energy practices of households involving control systems, such as smart metering and the billing system, especially the learning processes for these practices. In turn, this raises other questions: How are different energy controls and technologies used? How can their use be understood as part of social learning processes? This paper also aims to contribute to policy development in the field of assessing and evaluating government funded refurbishment projects. The paper is structured as follows: First, detailed background information about the project and the technical measures are presented. The methodology and theory are then considered, leading to an analysis of the empirical results. Discussion and conclusions finish the paper.

\section{Background}

There are 160,000 apartment blocks in Sweden, 67\% of which comprise rental flats (Hjortsberg, 2010). The neighbourhood under study consists of 900 flats and was built between 1969 and 1972 (see Figure 1). At that time, the Swedish government was using funding and planning measures to accelerate dwelling construction to meet the high demand for modern housing. The present case study examines a neighbourhood from this era that is typical in terms of design (large scale, rational floor plans, and flat roofs), construction material (concrete), energy system (district heating and mechanical ventilation), and equipment in flats (fully equipped kitchen and bathroom/laundry room). The supply of space heating, hot water and cold water were normally included in the rent, but tenants have individual electricity accounts, one for the grid connection and another for electricity supply. 


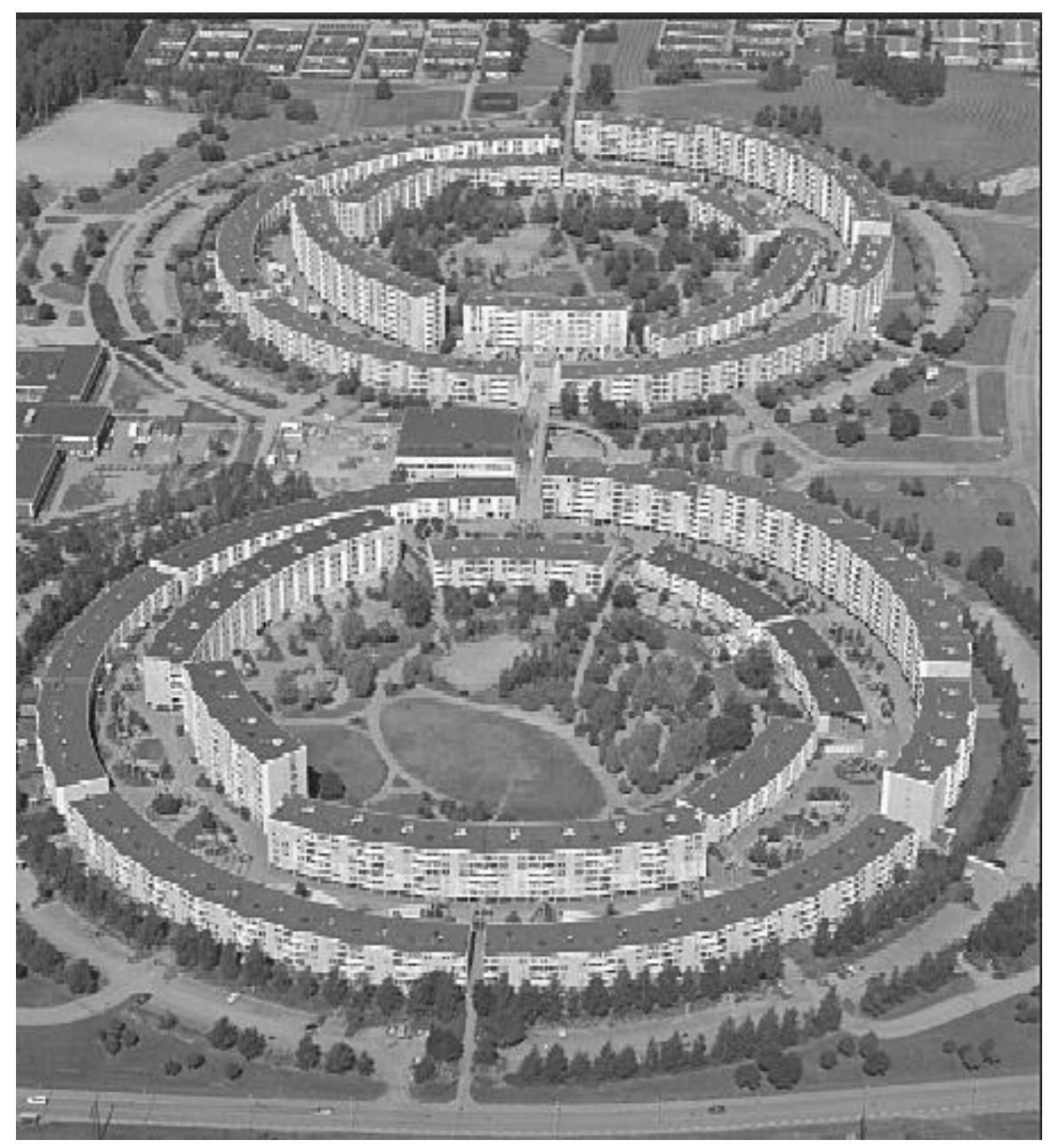

Figure 1. Ringdansen neighbourhood, Norrköping, Sweden, after the renovation of 1998-2004.

Since 1998, Swedish governments have allocated funds for investments in the built environment. The renovation of the Ringdansen neighbourhood was one of the first projects to receive funding. Ringdansen is owned by the Norrköping municipality housing company Hyresbostäder (HNAB). The first round of "local investment programmes" represented total funding of EUR 672 million (Swedish Environmental Protection Agency, 2010). With national government funding of EUR 26 million and local council funding, the Ringdansen project cost more than EUR110 million, making it by far the largest renovation project. ${ }^{1}$ Government funding for energy conservation in Ringdansen was granted primarily for implementing various technical measures, such as improved wall insulation and an additional layer of window glazing to complement the double glazing from the 1970s. The installation of solar hot water systems and large-scale geothermal groundwater heat pumps was initially proposed. The first proposal for government funding claimed as much as $70 \%$ savings for purchased energy would be possible. Due to a high vacancy rate in the area, the number of flats was reduced from 1600 to 900 . Some were rebuilt to meet a high demand for larger flats, others were converted to commercial spaces and schools, but many were ultimately demolished.

The proposed renovation system received a significant amount of negative feedback from university researchers and local politicians (Lövgren, 2002; Palm, 2004). HNAB's ideas were interpreted as an attempt to create an "energy island" independent of the local energy company that had been responsible for providing district heating to Ringdansen. District heating systems in 
Sweden are local monopolies so, unsurprisingly, some property owners try to find alternative heating options. At the time of the study, both HNAB and NME, the local energy company, were owned by the municipality of Norrköping. Some of the proposed technical measures were abandoned (i.e., solar hot water system and large-scale geothermal ground water heat pumps) and instead a smart metering and billing system (SMS) became the key part of the new energy system (Palm, 2004). The measures undertaken in the renovation are presented in Table 1. Thus, the focus shifted from energy producing measures to energy consuming measures and the goal for reducing energy consumption was reduced from a $70 \%$ to a $52 \%$. It was assumed that the pricing signal would provide economic incentives to the inhabitants to reduce their use of electricity, hot and cold water, and heating.

$>>$ Table 1 about here $<<$

The renovation targeted many aspects of Ringdansen's energy system and much can be learnt from the process and the results. Unfortunately, due to the complexity of all the implemented measures e.g., fewer flats, new tenants, and new building use, the results are difficult to assess (Vidén and Botta, 2006), as data collected before the renovation are difficult to compare with those collected after the renovation. ${ }^{2}$ Table 2 presents HNAB estimates that clearly indicate the major decline in resource use after the renovation project. Data for hot water use are unavailable.

$>>$ Table 2 about here $<<$

According to these data, the goal of reducing purchased energy was achieved. However, for the purpose of disseminating knowledge of these results, additional independent evaluations

(including the aspects of fewer flats, new tenants, and new building use) would be useful. ${ }^{3}$

\section{Description of the present energy system}

The neighbourhood's energy system is complex, consisting of several sub-systems interconnected in various ways. The most important technical parts of the system are: the building envelope; the heating, ventilation, and hot and cold water systems; and the metering and billing system (see Table 1).

The building envelope

During the renovation, the blocks of flats were refurbished in various ways depending on the identified needs. However, all buildings were equipped with new roofs, changing the design from flat to pitched roofs with extra insulation, and extra insulation was installed in the external walls. Many windows were replaced with low-emission windows, or an extra glass pane was added to the old window to increase the energy efficiency; the balcony doors were refurbished in a similar way.

The heating, ventilation, and water systems

Hot-water heating is used, and the ventilation is mechanical with a central exhaust fan - a heating and ventilation configuration common in modern apartment blocks in Sweden (of which approximately 64\% use district heating and 60\% mechanical exhaust ventilation) (Hjortsberg, 2010).

District heating is produced centrally in Norrköping and delivered to Ringdansen by the major energy company, EON. Heating distribution to each flat is controlled by Internet-based systems and technicians can monitor and regulate heating in individual flats by remotely opening and closing valves. However, routines are usually programmed and automatically carried out without manual intervention. Since conditions for comfortable indoor temperature and climate vary between flats, factors such as location in the building, number of rooms, and number of windows were mapped and recorded. Technicians said that this process took a long time and delayed the launch of SMS. 
The user interfaces for heating consist of a thermostat located in each flat's hallway and conventional water-filled radiators. The thermostat shows a few notches, and direction (+ or - ). All flats have only one indoor temperature zone and the individual radiators lack thermostats (Berndtsson, 2003). To lower the temperature in one room, tenants would have to use a handle to adjust the ventilation inlet - located behind the radiators, as is conventional in Sweden. Incoming air is normally below the indoor temperature but is heated by the radiators. The ventilation systems in the flats were kept as they were before the renovation, but heat recovery was installed and the recovered heat was used to heat the basement parking lots. The radiators are no longer constantly on, but cycled off and on depending on signals from the thermostat in each flat's hallway.

Water-saving measures were an important part of the refurbishment, and also helped save energy. Low-flush toilets and water-saving, single-handle faucets were installed.

The metering and billing system

The metering and billing system in Ringdansen is a "smart" system using meters that a) can collect and save data at constant intervals and b) offer a platform for customer-provider communication (e.g., a website) and automated meter management (Darby, 2010). SMS in Ringdansen combines various meters, platforms, and devices.

The energy systems and metering and billings systems in this neighbourhood are connected in several ways. All local distribution systems, including metering and billing, are collectively managed by the housing company. The web-based program has interfaces for both professionals (i.e., management and technicians) and residents. Professionals and residents can access energy use data from any device offering Internet access. In addition, professionals can manage various parts of the system in detail, down to the level of remotely closing or opening radiator valves in individual flats. Professionals can also access room temperature information for each of the 900 flats. Consequently, many temperature problems in flats can be dealt with from a distance and without personal contact between residents and technicians or management. Incoming calls or emails from residents with complaints are handled by the housing company's customer service and passed on to management or technicians.

The SMS system was installed in October 2001 but was only introduced to residents in April 2002. However, it was not until December 2009 that residents were billed for their actual energy use every month; earlier, billing was based on the previous year's use. In January, the actual use was compared with the preliminary billing; tenants then either received a refund or had to make an additional payment for the energy services used the year before. Now, the monthly rent invoice also includes detailed bills for heating, hot and cold water, and electricity.

Heating is metered by measuring the flow of district heating water to the radiators. Residents can monitor the daily flow and costs on the Internet, by logging into a personal account. The professional interface provides real-time information about heat flow and temperature, though the control devices and technology in the flats provide no indications as to temperature or costs. Many households also have their own thermometers to check the indoor and outdoor temperature.

The metering systems for water and electricity are similar. There are no visible water meters in the flats, but residents and professionals can monitor water flow and use on the Internet, though the available monitoring intervals differ between the professional and residential interfaces (and for electricity as well). The electricity meter is located in a cupboard accessible to residents, but the water meter is inaccessible to residents. Only professionals have access to the water meters. The end user interface on the Internet offers various use statistics and the ability to compare one's energy use with that of other neighbours (anonymized) in the same block. However, the precinct manager estimated that only approximately $5 \%$ of residents ever log on to the system. All energy 
use information (on both bills and the Internet interface) is in Swedish. Approximately $45 \%$ of Ringdansen residents were born abroad and Swedish is not their first language.

\section{Methodology and data collection}

The overarching methodological point of departure is that individuals are parts of bigger units and systems, such as the particular focus of this paper: socio-technical systems of energy (cf. Hughes, 1983). Earlier research into socio-technical systems has been criticized for not considering end users, instead focusing mainly on professional groups and stakeholders (Summerton, 1994). More recent research has addressed this lack of the end-user perspective by presenting the results of, for example, surveys (Darby, 2006a; Gram-Hanssen et al., 2004) and interviews (Darby, 2010; GramHanssen, 2010). Research including both householders and professionals is rarer but important, since both are stakeholders and essential to making new systems and technology work. The approach to this research is also guided by practice theory (Gram-Hanssen, 2010; Røpke, 2009) and the focus of the analysis is energy use practices in the Ringdansen neighbourhood. Shove stressed the study of "normal practices", since much of our resource consumption in general and energy use in particular is embedded in our everyday activities, habits, and routines (Shove, 2003).

The present research examines social learning in a neighbourhood that has been renovated to meet higher energy standards. Since a specific geographical area has been chosen and the starting point for exploring social learning is in the practices of people living and working in the area, the overall methodological framework is based on theoretical guidelines for case studies (cf. Yin, 1994). A case study is defined as a "contemporary phenomenon in the real-life context" (Yin, 1994, p. 13). Case study methodology encourages the use of a range of data collection methods as a way to assemble a comprehensive picture and case analysis (Yin, 1994). In energy efficiency research, the need for qualitative studies (Crosbie and Baker, 2010) and neighbourhood perspectives (Natarajan et al., 2011) has been acknowledged. Flyvbjerg (1991) has suggested that much can be learnt from "critical" or "extreme" case studies, since these generally provide more data . In many aspects, Ringdansen is a "normal" case, since residential areas of its age using the described technologies are common in Sweden; in other respects, however, Ringdansen is unique in the amount of government funding and the installation of some novel technologies. In the present case, results are based on (i) two years of observations made in the neighbourhood while accompanying professionals as they performed their usual duties, and (ii) formal interviews with some professionals. Observations were made by asking the local manager, smart metering technician, and some of the caretakers for permission to "shadow" them (c.f. Czarniawska, 2007). These observations were usually the starting point for identifying potential interviewees. All interviews were semi-structured and followed a conventional qualitative research methodology (Kvale and Brinkmann, 2008). The interviews with the professionals aimed to explore their everyday work related to energy systems and their interactions with residential tenants. The researchers compiled a list of 35 open-ended questions to give structure to the interviews. The questions were grouped into five categories: professional life background information, description of work tasks related to energy, professional collaboration with other staff, interaction with tenants, and views on drivers of and barriers to energy efficiency. The researchers met all of the interviewees in person and recorded and transcribed the interviews in detail. ${ }^{4}$ The researchers regularly met staff members (i.e., managers, project coordinators, and caretakers) and followed them during their working hours. Staff members were informally asked about their interactions with tenants; the researchers took notes and later summarized the answers in the office. One of the managers was also formally interviewed. Other professionals working in the area but employed by a different company (though with the same owner as HNAB) were interviewed formally. In total, the researchers formally interviewed 10 professionals with the following titles: head of heating, 
sanitation, and water; heating, sanitation, and water technicians; electrician; carpenter/general repairman; energy expert; smart metering expert; and business area and precinct managers. The aim of the interviews with residents was to explore their use and experience of heating, electricity, and water in their homes. The questions covered both their attitudes in these areas and everyday household practices involving energy use. Specific questions were asked about their use and experience of smart metering and billing and their communication and interaction with the housing company. All interviews except two were recorded and transcribed. ${ }^{5}$ In the cases in which interviewees rejected recording, detailed notes were taken and a fair copy was made immediately after the interviews.

The interviewed households were selected to obtain a representative sample of the various groups of people living in Ringdansen; country of birth, age, and family size were the main factors considered. In the interviews, the researchers also asked about education, profession, and income (Table 3) ${ }^{6}$ Lists of residents were provided by the housing company for various parts of the neighbourhood; the residents were called and asked whether they would like to be interviewed. Some declined for various reasons, but in most cases interviews were booked and conducted in the residents' homes.

The research benefitted from using both formal (interviews booked in advance) and informal (talk during the observations) methods to explore social learning in the neighbourhood. Both residents and professionals spoke openly during the observations. On one occasion, something that had been mentioned during the observations was asked about in the formal interview, and the interviewee was clearly uncomfortable. The digitally recorded interviews include a large volume of information and are essential to be able to quote interviewees. ${ }^{7}$ Issues of authenticity in qualitative research must be acknowledged; for example, one must consider interviewees' motives for granting interviews and whether their answers are genuine or simply what they believe the researcher wants to hear or what is "politically correct". Since most questions in the research dealt with people's use of technology and not specifically with the amount of energy used, and since follow-up questions concerned difficulties in performing various actions, the focus was not on performance in relation to how the interviewees wanted to portray themselves; interviewee inauthenticity should therefore not be a problem. This strategy has been used in the past when interviewing Swedish households (Skill, 2008).

\section{> Table 3 about here $<<$}

\section{Perspectives on social learning}

The present paper focuses on the aspects of social learning discernable in the socio-technical practices of energy use in Ringdansen neighbourhood. The interest in social learning stems from the many research results stating that it is important for social and environmental sustainability. However, since domestic energy consumption often involves the use of technology, a sociotechnical approach is suitable.

A socio-technical approach can be found in the social shaping of technology (SST) field, originating from the sociology of technology and various subdisciplines. In these fields, the social learning concept can be traced to the work of, for example, Rip et al. (1995), Sørensen (1996), Sørensen and Williams (2002), and Williams et al. (2000, 2005). What was new in the SST perspective was the acknowledgement that various interpretations and uses of design were possible and that political intentions and ideas could be built into designs of technology (Stewart and Williams 2005). For example, the first Swedish low-energy "passive" houses were explicitly designed to suit a family of two adults and two children, commonly known as the "nuclear family" and for many years a political ideal (Glad, 2006). However, around half the households inhabiting these houses comprised fewer than four household members, making it difficult to obtain a comfortable indoor climate (Isaksson 2009). An SST-related question would be why the "nuclear 
family" was chosen as a standard. Early work from the SST perspective traced the ideas of designers and producers that were built into technology; little attention was paid to the actions of end-users. In later work, technology is perceived as co-produced by designers and producers, on one hand, and by users on the other (Jasanoff, 2004). This later perspective accords the users a more active role in implementation.

Empirical work using social learning theory as an analytical framework is mainly found in the area of information and communication technology (ICT), for example, in the work of Silverstone et al. (2002), Oudshoorn et al. (2004), and Büscher et al. (2001). Recently, social learning related to the use of various energy technologies has also been acknowledged (cf. Darby, 2006a; Stagl, 2006; Vergragt, 2006).

A good starting point for understanding social learning is Sørensen's useful definition (1996, p. 6): [Social learning] can be characterised as a combined act of discovery and analysis, of understanding and giving meaning, and of tinkering and the development of routines. In order to make an artefact work, it has to be placed, spatially, temporally, and conceptually. It has to be fitted into the existing, heterogeneous networks of machines, systems, routines, and culture. From the users' perspective, technology has to be available for discovery and the users must have the opportunity to think and reflect on what they have experienced with their senses. Technology, including parts of technological systems, is sometimes hidden from users and is difficult to experience. Many modern technologies are not intuitively understandable for everyone since the designers and producers of modern technology are so much more conversant with the technology than end users are. In addition, users are disparate, making it impossible to speak of a single group of users, since there are so many. Designers and users of modern technology probably think about the contexts in which technology will be used but, since the everyday lives of users vary endlessly, it is impossible to imagine every possibility. Referring to Sørensen (1996), technologies of everyday life form heterogeneous networks of technology - i.e., hardware, software, and the social systems of routines and culture. The implementation of novelties is not placeless; rather, the success of innovations is largely dependent on where (i.e., the physical context) and when something is introduced. The circumstances of previous research into social learning related to most ICTs differ significantly from those of current research into energy systems. The energy systems in the studied blocks of flats were not chosen or purchased by the end-users or any of the professionals working with them today. Interaction with these systems is not voluntary in the same way as is learning about how a computer works. Another important difference is that the social focus of previous research has been the relationship between household members and perhaps their friends and neighbours. However, the present research has an expanded focus to include professionals as well.

Social learning theory, as introduced by Sørensen, gives rise to the following themes that guide the analysis of the empirical data: user access to technology (physical and cognitive), communication (between users), trust (in technology and between users), social roles (of users), and co-production of technology.

\section{Smart metering from a social learning perspective}

Results are presented and analysed focusing on the various relationships between two groups of users: households and professionals. A specific focus is on how practices related to retrofit measures can be understood as parts of a social learning process involving both professionals and tenants. Different parts of the system present different opportunities for "discovery and analysis", to use the words of Sørensen (1996). These opportunities and the access to parts of the system also vary between different groups of professionals and tenants. How groups of users understand, attribute meaning, and include energy systems in everyday routines are also considered in the analyses. 


\section{Physical and cognitive access to technology}

From a social learning perspective, it is relevant to consider whether a technology is being used as was intended by its designers and by the professionals who chose to install it (Aune et al., 2002). What are the physical and/or cognitive constraints preventing the intended use? The Ringdansen energy system was introduced to an already well-known physical environment at a turbulent time when the buildings and their socio-cultural environment were being changed radically (Lövgren, 2002). The heterogeneous networks forming in the neighbourhood consist of traces of both past and present. Some features of the neighbourhood, such as its location and the general "O"-shaped arrangement of the buildings, were still the same, but the various subsystems around which practices formed were all changed in the renovation and retrofitting processes. The most encompassing change made to the system is the smart metering and billing system (SMS) that meters and monitors heating, electricity, and hot and cold water consumption. Energy is an invisible good bought by tenants in the form of electricity, heating, and hot water. Many people find energy abstract and difficult to grasp intellectually. How energy is distributed and billed for in Sweden unfortunately does not always contribute to a better understanding of it (Sernhed, 2008). Heating was usually included in the rent, as is hot and cold tap water, and is therefore rendered invisible. The smart metering system for managing energy use was installed, transferred this the responsibility for reducing energy consumption to Ringdansen tenants. It was assumed by the client and their professional team that smart metering would make energy use and costs more visible, generating economic incentives for reduced use. Smart metering could make it possible for tenants to discover energy in new ways.

In the first years of SMS implementation, HNAB found that some tenants found the system difficult to understand (Berndtsson, 2003). According to Hyresbostäder employees, the housing company had largely failed to give accurate feedback to its tenants on the environmental effects of household energy use. The facilities manager acknowledged the need for such feedback, but explained that he lacked the resources to provide it. In 2009, the system and communication with professionals were still issues:

I don't really like this system. I spoke to a technician earlier, but he used such technical terms that I didn't understand anything. (Household \#3)

Approximately 10-15 home visits had to be made annually to tenants who thought the figures on the bill were wrong (Berndtsson, 2003). These visits were made by local HNAB representatives; they were initially technicians, but local caretakers, also employed by HNAB, later learned how to make home visits. Home visits involved various measures depending on the issue reported. For a report of faulty water billing, for example, a caretaker would visit the residents when they were at home. The caretaker would bring a 10-L bucket and, while the tenant watched, the door to the pipes and meters in the bathroom was opened with a special key that the tenants did not possess. The caretaker would point to the cold water meter and ask the tenant/tenants to watch the meter while they opened the cold water tap and filled the bucket with water. In every case so far, the meter has been correct, according to HNAB. As Sørensen (1996) stresses physical contact with technology in a social learning process, the physical placement of the water meter was problematic. In the SMS design, meters could be read on the web. Some interviewees said that they used the internet and sometimes logged into the system to check their consumption of heating, electricity, and hot and cold water. Others thought it was sufficient to check the figures once a month when they received the rent invoice (which included smart metering data and charges for energy and water). According to HNAB, only about $5 \%$ of all households in Ringdansen ever logged into the system. One householder's response is quite telling: Interviewer: Do you check on the Internet how much energy you use? Respondent: How do you do that, then? 
Interviewer: You can log into a website that shows your own data and see statistics about how much energy you are using, and compare this with how much you used before and with other tenants in the block.

Respondent: Oh, I didn't know you could do that. I will tell my husband - he will think that is really exciting. (Household \#11)

The use of smart metering is constrained by both physical and cognitive factors. Although $89 \%$ of Swedish households have Internet access at home (Statistics Sweden, 2011), Internet use does not necessarily follow. The design of the present system, in which users must log into the system and the information is presented only in Swedish, does not facilitate use, since almost half the residents do not have Swedish as their mother tongue.

The use of thermostats has previously been the focus of academic research (Kempton 1987). Kempton concluded that professional technicians have one way of using thermostats, setting them and letting them do their job, while many residents (up to 50\% according to Kempton) might use the thermostat to "boost" the indoor temperature and then turn it down when the desired temperature is reached. According to Kempton, both practices can be rational depending on one's knowledge of the specific energy system and building envelope (tenants tend not to have that knowledge). In the present case, the thermostat gives very little information to users, no numbers being present on the device. This gives flexibility to the housing company to regulate the maximum temperature.

For almost eight years of operation, the thermostat in each flat's hallway had allowed tenants to choose a temperature between 18 and $24{ }^{\circ} \mathrm{C}$. When the new housing managers came to the neighbourhood in 2008, more attention was paid to sustainability. According to the managers, a 24 ${ }^{\circ} \mathrm{C}$ indoor temperature, even if tenants paid for the heat themselves, was not sustainable. A decision was made, in agreement with the tenants' association, that the maximum indoor temperature attainable by turning up the thermostat would be $22{ }^{\circ} \mathrm{C}$. Previous research in Sweden has found that if householders can choose a higher indoor temperature and are willing to pay for it, they will choose a higher temperature than the professionals (e.g., architects and electrical engineers) assumed when planning and constructing a building (Ruud and Lundin, 2004).

A month before the launch of the new option range for indoor temperature, an information campaign began and every household received a leaflet in the mail. In addition, posters conveying information on the subject were displayed on the bulletin boards at all entrances of every residential building affected by the new policy. The new temperature range was launched in the autumn before what turned out to be one of Sweden's coldest winters in 20 years. Consequently, some tenants experienced problems with low indoor temperatures. According to HNAB representatives, the unusually cold winter also influenced tenant perceptions of climate change issues, and HNAB found it more difficult to advocate and implement energy saving measures. Caretakers were busy for several months, as tenants frequently called the service line and filed complaints about indoor comfort. Since the tenants' association had agreed to the new heating conditions, tenants had to adapt to the new circumstances. Two relatively new tenants talked about their experience as follows:

Respondent 1: I thought that it [i.e., the thermostat] would be better than it was. I thought that it was [good] to have a thermostat indoors, because I've only seen them on TV, but later I was ... Respondent 2: Always in American movies.

Respondent 1: Yes, everybody has a thermostat as a temperature control device, and they can lower their thermostat because it is often very warm inside. But with us it's more like ...

Respondent 2: Turn up the thermostat because it's so cold!

Respondent 1: Yes, it's like that here. (Household \#19) 
The functionality of the thermostat used in Ringdansen can be questioned. Not only is its design problematic, with increments that mean nothing to the tenants, but the device was not properly introduced to tenants, who do not understand how to use it properly.

Attached to the thermostat in every flat is a "going out" button, which residents also called the "absent" or "saving" button (some caretakers and residents referred to this as the "man" button, since the light that goes on when pushing it is shaped like a man). Pressing this button lowers the indoor temperature to a minimum of 18 degrees. According to HNAB, many tenants frequently use the absent button when leaving their homes. With every new lease, the housing company briefly introduces new tenants to the systems they will use when living in Ringdansen (mainly heating, recycling, and laundry). HNAB claims that by using the absent button, tenants can "save lots of heating [energy] without having any inconvenience of low indoor temperature"

(Berndtsson, 2003).

As in several other cases (cf. Isaksson, 2009; Green, 2006), the tenants' perceptions of convenience differed from the housing company's. One family with two children found that it was "terribly cold downstairs" (they lived in a two-level flat) when they had just moved in, and described their first experience of the heating system as follows:

The guy who manages the heating came here and showed us that, because the thermostat is in the hallway and we have aquariums and things like that, it becomes very hot. So in the hallway it was about 22-23 degrees and then that would not let the heat come on. So he said that we should shut off all the radiators and things on the upper level and then set it [i.e., the thermostat] to maximum for it to reach over 23 degrees, or to under 23 for it to turn the heat off. So then it got better, since we were only heating from below, and it [i.e., the heat] could rise then. (Household \#12).

The thermostat was not only difficult to manage, but also difficult to refer to accurately. In the interviews, the respondents referred to it as "that" or "it" or something similar. Most of them did not understand that it was a thermostat or how to use it. The family referred to above found it easier to understand the heating system once the heating manager had explained how the thermostat worked and showed them some tips and tricks. Initially, the family believed that if they set the thermostat pointing straight up, they would get 20 degrees. After being shown in their flat how to manage the thermostat, they stated that "they were able to learn". If they turned off the aquarium light, they could even lower the thermostat, since it would let the heat come on anyway. This is an example of how social learning in the meeting between professionals and tenants was important in managing the heating system.

\section{Trust in technology and between users}

Trust has been an issue as new energy systems have been introduced in other contexts (Isaksson, 2009; Sernhed, 2009; Aune, 1998). In the present case, trust can be attributed to various aspects of the socio-technical system: to the technical system itself, to the housing company's choice of technical solution for metering and billing, and to the communication between professionals and tenants. Trust in the system in this case will be exemplified by user experience of the heating system.

Heating was described as the most complicated part of the SMS system. The main reason was that the metering of heating is not standard in Swedish rental flats, so experience of introducing metering to an existing heating system was lacking. According to one professional who has worked in the neighbourhood for almost 10 years, smart metering in the flats was not a good idea (Professional \#10). The technical personnel put a lot of effort into the project before and after the retrofitting to make the system work. The fact that the housing company has not installed the smart metering and billing of heating in any of its other properties signals failure. In addition, most tenant complaints to the housing company have concerned problems with space heating in the flats. Both the professionals and tenants have experienced a system with constant faults and 
problems, and this does not facilitate trust. Even so, the professionals, as representatives of the housing company, must comply with the company's intention to keep the system operating in this neighbourhood.

In the observations, one main theme frequently encountered was that of building trust. It was mainly tenants' trust in the metering system that was an issue. Several strategies have been developed and now form informal protocols for professional action. A protocol for following up on "low indoor temperature" would look like the following (field notes from an observation): " $X$ " [i.e., the caretaker] received a message on her palm computer while she was cleaning the stairwell. One tenant had called customer service about low indoor temperature. To deal with this, $X$ had to fetch a certain thermometer from the area office before visiting the complaining tenant. We did that and then went to the tenant and rang the bell. A man answered the door. It was steaming hot inside. We removed our shoes and entered the flat. The thermometer was put on the thermostat situated in the hallway of the flat. The caretaker then asked the tenant to come along while she entered first the living room, then the bedroom and the kitchen to see if the radiators were fully open. The thermometer showed 21.2 degrees Celsius, but the valves on the radiators in the bedroom and living rooms were closed. "..." [the caretaker] opened the valves and asked the tenant to call again if the indoor temperature did not reach 22 degrees in a while.

Low indoor temperature is a common complaint, especially in autumn before tenants have become acclimatised and the heating system has been regulated to deal with colder and more humid conditions. It has become part of the caretaker's job to prove that the system is operating correctly and that the tenants' perceptions are wrong when there are complaints about low indoor temperature, usually in the autumn. The tenants do not have thermostats on their radiators as in most Swedish homes; instead, the temperature is regulated using the thermostat in the hallway. Consequently, it is difficult to have different temperatures in different rooms. The tenants are also told that it is inadvisable to put furniture or curtains in front of the radiators, as this will hinder the heat from diffusing in the rooms. What is also pointed out to the tenants is that the fresh air intake from the outdoors is behind the radiators and consists of a vent that is difficult to regulate. Since draughts are perceived as a problem, due to an excessive intake of fresh air, caretakers devise their own solutions that diffuse among them, including the advice to use fabric to cover the fresh air intake vent. Some caretakers even provide tenants with sponges that are cut to fit the vents. The energy system still required further adjustment with traditional forms of insulation to block (or moderate the flow of) unwanted incoming air. This also proved to be a strategy for building caretaker-tenant trust, though it was not approved by technicians or area management. Caretakers met tenants personally on a daily basis and felt sympathy when they complained about feeling cold indoors. The use of sponges or fabric to stop draughts had become normal for caretakers and provided a solution to problems that they saw management ignoring. However, management acknowledged that problems could arise from such "amateur" solutions and organised training for caretakers. The training was hierarchically organized, and the caretakers were shown practical tools for dealing with various problems, primarily energy related. While the caretakers knew about the problems, due to their everyday contact with tenants, the technician had the solutions. The results of this research indicate that caretakers have gained knowledge from their close contacts with tenants, and that an alternative approach would be for caretakers and technicians to exchange knowledge. The training might also include various types of feedback, making learning a circular rather than a top-down process.

At another level, the issue of trust involves whether the landlord purchases the same services that individual households would normally choose. From an international perspective, Sweden's “allinclusive" rental flats are curiosities. In Ringdansen, even electricity is metered and billed through HNAB and is procured centrally. Residents of Ringdansen cannot individually choose the 
company from which they would like to buy electricity. According to HNAB, the electricity delivered is produced in an environmentally friendly way and the bulk purchase contract is more advantageous than any contract a household could get on its own. Many Swedes, especially low energy consumers, such as tenants of multifamily residential buildings, tend not to be active on the deregulated Swedish energy market (Bladh, 2007). According to the interviewees, having HNAB manage the electricity provision was advantageous, and most residents trusted HNAB to negotiate a good deal for all the residents.

Interviewer: Would you like to choose [the energy company] yourself?

Respondent: For electricity? No, I don't need to do that - they [i.e., HNAB] know better.

(Householder \#15)

HNAB cut electricity costs by reducing the number of delivery power points to the Ringdansen neighbourhood. Consequently, every household must buy electricity via the housing company. HNAB procures the electricity, measures its consumption in all households, and bills the tenants an unusual arrangement in Sweden. Tenants usually have two contracts, with the grid owner and electricity supplier respectively. In the studied case, HNAB assumes both roles, since it owns the precinct grid and can act as intermediary between tenants and electricity suppliers. Residents rarely question this arrangement; when they do, the local manager argues that no tenant could get a better electricity rate on his or her own, since HNAB with its 900 flats can buy electricity in bulk. From another perspective, tenants have no say in their choice of electricity supplier, which runs counter to the intention of the government's deregulation initiatives of the 1990s.

The above phenomenon can be analysed in terms of stakeholders with ambiguous roles (Sernhed 2008). The tenants examined here are both consumers and clients purchasing space heating, electricity, and hot and cold water via their housing company, as well as important agents helping the housing company realise its energy saving goals. In this way, tenants play an ambiguous role in the neighbourhood, as do the housing company and the technical/maintenance professionals. The ambiguity lies in the various demands associated with "being a Ringdansen tenant". As a tenant, one is both a client, consuming energy and paying for energy services delivered by the housing company, and a change agent who is expected to save energy and consume less. From the tenant perspective, the housing company can be expected to encourage both consumption (to earn money) and economizing (to achieve energy saving goals). The reverse applies to HNAB and the professionals, who act as both suppliers and energy advisors for the tenants. These roles were not overtly discussed, though they influence the professionals' relationships and their potential roles as partners in the social learning processes. Ambiguous social roles are likely to be barriers to social learning in the interest of energy savings if households are expected to learn about energy saving measures from professionals.

\section{Communication between professionals and tenants.}

Communication has been presented as a key to social learning (Sørensen, 1996). Previous research into new domestic energy systems has focused on communication between household members (cf. Isaksson, 2009; Aune, 1998). One conclusion is that discussing issues and imitating those who found solutions to problems seem to be common strategies. Communication also occurred with neighbours and the housing company (cf. Isaksson, 2009).

The following anecdote, from one of the participant observations conducted in the autumn with the "SMS expert", exemplifies dysfunctional communication between a professional and tenant. The visit was defined as typical by the technician. The lady who opened the door for us was standing in a t-shirt holding her arms around her like she was very cold. She showed us that her thermostat was turned to maximum, which at that time was 24 degrees. The other occupant, her husband, complained about her excessive use of heating and the high bills, but she explained that it was necessary for her comfort. She explained her reasoning about the low indoor temperature 
and pointed at the balcony door, saying that it felt like the source of the draught. The technician started to examine the flat and looked at the ventilation outlets, windows, and the balcony door. He said that a carpenter would take a closer look at the door. After the researchers had left the flat, the technician expressed his views on the issues. The primary problem was the clothes that she was wearing: put on a sweater in the autumn was his prescription to solve the problems she was complaining about. For him, it was obvious that some tenants have "lost old knowledge" about dressing properly indoors during colder times of the year. However, this was not something he could tell tenants directly and not something that he considered teaching tenants about.

Similar dysfunctional communication, although personal contacts had been made, is exemplified in the following anecdote. One of the "regulars" calling customer service was well known to the caretakers. This woman was living with her daughter and had moved from one flat to another in the same neighbourhood, so a few caretakers had experience of visiting her. She repeatedly called to complain about the low temperature in her flat, and when caretakers visited her she was always wearing a t-shirt and went around during the heating season without slippers on. She used her oven as an electrical heater and her daughter sat in the kitchen with a blow drier turned on in order to raise the temperature. The caretaker visiting perceived the indoor climate of her flat as like "a sauna". Both repairmen and energy technicians had examined the flat previously, but none had found any "technical problems".

Sometimes, the technician explained to the researcher, complaints were filed for mainly social reasons. Some people who stay home in the daytime would call customer service and ask a caretaker or technician to come and look at something when what they really wanted was a few minutes of company. Other tenants were never home in the daytime, and caretakers and technicians found it difficult to try to resolve their problems since HNAB policy forbids professionals from entering flats unless the tenants are at home.

During the observations and interviews, the perception was that in many situations caretakers and technicians were unsure of how to proceed when the problems were best solved by behavioural change. Professionals representing the housing company and who regularly meet tenants in their homes should be among the most suitable personnel to communicate with the tenants. However, they obviously lacked tools with which to approach tenants about what they perceived as the true problems and solutions. Professionals thought that focusing on the building envelope and on various technical installations would be easier ways to tackle the problems than confronting people about their inadequate clothing and lack of activity. On rare occasions, complaining tenants had indoor temperatures of 25 degrees. One repairman explained this by referring to the geographical origins of these tenants:

Then it is like some ... come from slightly warmer countries, and they are used to that and have a hard time adapting... (Professional \#7)

The repairman hesitated when talking about this possibility, and displayed signs of being uncomfortable about seeking explanations in tenants' immigrant backgrounds. Such explanations are usually considered politically incorrect in Sweden.

Another approach used by professionals was to play some "tricks" on the tenants. Repairmen described how they sometimes simply removed the handle from the radiator and put it back again. This measure would not influence the heating system, but was usually enough to satisfy the tenant. They then would ask the tenant if the situation was better, and the tenant would reply "yes, much better". The repairmen justified the trick by claiming it was sometimes necessary to take "psychological measures". A group of caretakers also described how they sometimes felt the need to "lie" to certain tenants.

\section{Co-production of smart metering}


Theory suggests that it is through its use that technology is defined, in what is called the coproduction of technology (Jasanoff, 2004). Technology is not simply designed and produced for a specific context but must be co-produced with its end users. In this case, all the flats and households represent different contexts. In co-production processes, micro-perspectives (i.e., householders' perspectives) and macro-perspectives (e.g., national energy efficiency goals) meet. Jasanoff also suggests that co-production must seek a balance between stability (e.g., establishing a new routine) and change (developing the neighbourhood to increase sustainability), and between knowledge and practice (e.g., knowledge of how energy systems work and professionals' and tenants' practices to cope with the systems). The co-production of water use displays promising features related to energy efficiency goals.

The SMSs examined in the international literature usually concern electricity (Darby, 2010, 2006b). In the studied case, however, electricity is only one of four systems included in the Ringdansen SMS (electricity, hot water, space heating, tap water). The national housing authority suggests that individual differences in tap water consumption usually account for differences in energy use (Swedish National Board of Housing, Building and Planning, 2002). Consequently, the individual metering and billing of tap water is relevant from an energy saving perspective. In the interviews with tenants, the initial question about energy was an open-ended one about what the respondents associated with the word energy. Only two responded "water". One respondent stated:

Water is not a problem [i.e., compared with electricity, where you do not know what appliances and practices are consuming it in what quantities]. (Householder \#4)

However, after giving the use of water in the household a second thought, the respondent reasoned about common practices in their household: washing up after a meal, personal hygiene, and watering the potted plants. The conclusion was still "it works fine - water consumption is the easiest thing to regulate".

The husband rinses the dishes carefully by hand before putting plates, cups, glasses, etc., in the dishwasher - "the dishes look almost clean" according to the wife. She prefers to remove scraps with a knife or fork and then run a long programme in the dishwasher. The difference in procedure is the subject of discussion in the household. The response clearly indicated that water use was a negotiated process in the household. Other water saving practices are taught by the mother to the children. The tooth brushing practice includes a simple rule: When the toothbrush is in the mouth, the water tap should be closed. This household has spoken to friends about their water consumption, and concluded that their use of water is "very low".

The introduction of volumetric billing in Ringdansen was an issue all through the renovation process. Residents claimed the old system was either a "joint responsibility" or "unfair", though the latter evaluation was supported by the housing company. Consequently, representatives of the housing company introduced arguments such as the following:

Why should you, living in a single-person household, pay for households of ten or households using water in a wasteful way? (Krantz, 2005, p. 67)

Smart metering and billing was launched as a solution to an unfair system, but the talk about fairness also prompted other discussions about the use of hot water. One interviewed tenant mentioned the inconvenience of living on the top floor. She had to open the hot water tap for a long while before having hot water. She regarded this as a waste of water and money for her. When she shared this experience with another tenant during one of the resident meetings organized by HNAB, another tenant told her about how she usually kept a bucket near the hot water tap in the bathroom and filled it with the water that otherwise would be wasted and only flushed away. The inconvenience of not having immediate hot water flow from the hot water tap is probably something most residents experience, but discussion of a solution to wasteful behaviour 
would probably not have occurred without the installation of the "new" system. The resident meeting organized by HNAB facilitated such sharing of experience and mutual learning.

\section{Discussion}

The project took a radical turn when the energy efficiency and savings focus shifted from energy producing measures to energy consuming measures, though the organization had not been developed to manage and support either the tenants or technical/maintenance professionals in their new roles. The housing company displayed a laissez faire attitude towards the end user aspects of smart metering and the various problems that might be expected from introducing a new system previously unknown to both professionals and households. Theory suggests that end user difficulties must be taken seriously, even though a technology may seem intuitive and elementary to technicians and professionals (Summerton, 1994; Sørensen, 1996; Darby, 2006a; Isaksson, 2009).

Previous research into how end users assimilate new technology into their existing socio-technical environment indicates that this involves processes of social learning: discovery, analyses, giving meaning, tinkering, and developing new routines (Sørensen, 1996). The tenants in this case study have limited opportunities to discover the energy system through the means available to them. Advances in interface design seem in some ways to have passed unnoticed in the energy technology field. Lost opportunities to discover the energy system, since meters and other devices are hidden from tenants, for example, behind locked doors, consequently limit other activities associated with social learning.

There is a significant gap between how professionals understand and attribute meaning to the heating system and how tenants are involved in social learning. Professionals have an advantage over tenants when it comes to formal knowledge of the system, but how the energy system works in households is important, too. There are opportunities for social learning between professionals and tenants, since professionals are based and employed in the neighbourhood, but these opportunities have not been seized. Such opportunities arise in the use and management of the heating system after complaints are filed, since then professionals and tenants meet and interact in tenants' homes. Theoretically, the SMS communication platform is what makes the system "smart" and what lets users learn about energy savings (cf. Darby, 2006a). Since only approximately $5 \%$ of the households ever logged into the system, however, it must be considered a failure. The electricity system offers opportunities for social learning, since the housing company controls the purchase, distribution, metering, and billing of electricity in the neighbourhood. This degree of control, which is unusual in Sweden, arguably entails responsibility to communicate with tenants about electricity use and energy saving measures in the home.

Hot water became an issue in the neighbourhood when volumetric billing was proposed and introduced. During the retrofitting process, there was debate about whether the old system was a symbol of resident unity or whether it was unfair to small users. Minor fairness issues are still present and could be managed using social learning as a tool, for example, by having tenants and professionals share their experience of water saving measures. Due to its relative visibility, water use and costs are perceived as easier to regulate and manage in tenants' everyday practices. In terms of energy saving, hot water could be a priority meriting direct attention. Hot water might be a good starting point for communication and interaction about energy savings in households. Some technical prerequisites are already in place: single-handle taps, individual meters (although currently hidden from tenants), and the Internet platform. Putting these resources together would allow professionals and tenants to work together to realize increased savings.

In the development of social learning for energy efficiency, in its normative sense, limits to approaching end users about their practices must be addressed. Professionals avoid certain topics, 
such as tenants' clothes, but are happy to make suggestions about how to furnish the apartments. In addition, professionals mislead tenants about how they manage energy-related problems in the flats. This is not a sustainable relationship between professionals and households and is a barrier to social learning.

\section{Conclusions}

The energy system installed during the renovation of Ringdansen is not optimal, from either the technical or user perspective. Looking back at the proposal for a new energy system, considerable emphasis was placed on producing heat locally, which was not optimal given the connection to district heating. One suggestion for future renovations is to focus on the buildings' envelopes and energy systems. This has often been stressed in prior research and should not have been news to the building proprietor in the studied case; however, it seems hard to keep that focus in actual projects.

Once an energy system is in place, it is in the hands of its users, both professional and inhabitants. Few systems are self-instructive or intuitive, and this is true of the smart metering and billing system examined here. Consequently, learning how to use the system is key to its optimal functioning. Social learning theory has showed that the present energy system is not facilitating learning. Important user interfaces, such as instant metering feedback to reinforce understanding and learning, are hidden from users. From the users' perspective, the system is not smart. Much can be learnt from introducing a new energy system that includes smart metering and billing. The retrofitting of the Ringdansen neighbourhood, which introduced such a system, can be defined as only partially successful. This success is gauged by the fact that fewer resources are used in the neighbourhood. Exactly how energy efficient the area has become has never been clarified, however, since proper means to evaluate and assess the renovation are lacking. An important policy implication is that the means to evaluate and assess results must be determined early in a project to secure relevant baseline data from before the renovation. Resources must also be allocated to collect, analyse, and disseminate evaluation and assessment results as well as for further incorporating the results back into policy and practice.

\section{Acknowledgements}

The author greatly appreciates the generous financial support of the Swedish Research Council Formas. This research is part of the research project Collaboration for sustainable use of resources in the housing environment. The author acknowledges helpful comments on this paper from the technology, everyday life and society seminar at Linköping University's Tema Technology and Social Change Unit and Michael Ornetzeder, Austrian Academy of Sciences.

\section{References}

Aune, M.(1998) "Nøktern” eller "Nytende”? Energiforbruk og hverdagsliv i norske husholdninger, Senter for teknologi og samfunn, Norges teknisk naturvitenskaplige universitet, Trondheim.

Aune M., Becker T., and Sorensen K. (2002) Needs, Roles and Participation. A Review of Social Science Studies of users in Technological Design, NTNU,

Department of interdisciplinary studies of culture, Trondheim.

Berndtsson, L. (2003) Individuell värmemätning i svenska flerbostadshus - en lägesrapport, Statens Energimyndighet, Eskilstuna.

Bladh, M. (2007) El nära och långt borta: hur kan hushållen agera på elmarknaden?, Tema T, Linköpings universitet, Linköping.

Büscher, M., Satinder G., Preben, M. and Shapiro D. (2001) Landscapes of practice: bricolage as a method for situated design. Computer Supported Cooperative Work, 10(1), 1-28. 
Crosbie, T. and Baker, K. (2010) Energy-efficiency interventions in housing: learning from the inhabitants. Building Research and Information, 38(1), 70-79.

Czarniawska, B. (2007) Shadowing and other techniques for doing fieldwork in modern societies, Liber, Malmö.

Darby, S. (2003) Making sense of energy advice, in Proceedings of the European Council for an Energy-Efficient Economy, Paper 6,157. ECEEE, Stockholm.

Darby, S. (2006a) Social learning, household energy practice and public policy: lessons from an energy-conscious village. Energy Policy, 34, 2929-2940.

Darby, S. (2006b) The effectiveness of feedback on energy consumption. A review for DEFRA of the literature on metering, billing and direct displays, Environmental Change Institute, University of Oxford, Oxford.

Darby, S. (2010) Smart metering: what potential for householder engagement? Building Research and Information, 38(5), 442-457.

Glad, W. (2006) Aktiviteter för passivhus: en innovations omformning i byggprocesser för energisnåla bostadshus, Linköping Studies in Arts and Sciences, Linköping.

Gram-Hanssen, K. (2010) Residential heat comfort practices: Understanding users. Building Research and Information. 38(2), 175-186.

Gram-Hanssen, K., Kofod, C. and Nærvig Petersen, K. (2004) Different everyday lives: Different patterns of electricity use, in Proceedings of the 2004 American Council for an Energy Efficient Economy, ACEEE, Washington DC.

Green, A. (2006) Hållbar energianvändning i svensk stadsplanering: från visioner till uppföljning av Hammarby sjöstad och Västra hamnen, Linköping Studies in Arts and Sciences, Linköping. Hjortsberg, M. (2010) Description of the Swedish building stock using material from a Swedish statistical survey of 1800 buildings, the Swedish national board of housing, building and planning, Karlskrona.

Isaksson C. (2009) Uthålligt lärande om värmen?: Domesticering av energiteknik i passivhus, Linköping Studies in Arts and Science, Linköping

Jasanoff S. (2004) "The idiom of coproduction" in Jasanoff (ed.) States of Knowledge: The Coproduction of Science and Social Order, Routledge, London.

Karlsson, K. (2008) Kort om de miljöåtgärder som genomförts i Ringdansen, Miljöinvest, Norrköping.

Kempton, W. (1987) "Two theories of home heat control" in Holland D \& Naomi Q. (eds) Cultural models in language and thought, Cambridge University Press, Cambridge:

Kollmuss, A. and Agyeman, J. (2002) Mind the gap: why do people act environmentally and what are the barriers? Environmental Education Research, 8, 239-260.

Krantz, H. (2005) Matter that matters: a study of household routines in a process of changing water and sanitation arrangements. Linköping Studies in Arts and Sciences, Linköping.

Kvale, S. and Brinkmann, S. (2009) InterViews: learning the craft of qualitative research interviewing (2. ed.), Sage Publications, Los Angeles.

Levine, M. and Ürge-Vorsatz, D. (2007) Residential and commercial buildings, in Metz, B., Davidson, O.R., Bosch, P.R., Dave, R., and Meyer L.A. (eds) Contribution of Working Group III to the Fourth Assessment Report of the Intergovernmental Panel on Climate Change, Cambridge University Press, Cambridge, United Kingdom and New York, NY, USA.Lutzenhiser, L. (1993) Social and behavioural aspects of energy use. Annual Review of Energy and Environment 18, 247289.

Lövgren, S. (2002) Att skapa ett framtidens folk: governmentality och miljödiskurs i modern svensk bostadspolitik : miljonprogramsområdet Navestad, Linköping Studies in Arts and Sciences, Linköping. 
Moloney, S., Horne R. E. and Fien, J. (2010) Transitioning to low carbon communities - from behaviour change to systemic change. Energy Policy 38, 7614-7623.

Natarajan S., Padget J., and Elliott L. (2011) Modelling UK domestic energy and carbon emissions: an agent-based approach. Energy and Buildings 43 (10), 2602-2612. Oudshoorn, N., Rommes, N. and Stienstra, M. (2004) Configuring the user as everybody: gender and design cultures in information and communication technologies. Science, Technology and Human Values, 29(1), 30-63.

Palm, J. (2004) Makten över energin: policyprocesser i två kommuner 1977-2001. Linköping Studies in Arts and Sciences, Linköping.

Rip, A., Misa T. J. and Schot J. (eds) (1995) Managing Technology in Society: The Approach of Constructive Technology Assessment, Pinter, London and New York.

Ruud, S. H., Lundin, L., Sandberg, M., Nielsen, J. R., Wahlstrom, Å., Törnström, T. and Kovacs P. (2005) Houses without a traditional heating system - Results from two years of measurements, in Proceedings of the 2005 Sustainable Building Conference, SB05, Tokyo.

Sernhed, K. (2008) Energy services in Sweden: customer relations towards increased sustainability, University Press, Lund.

Shove, E. (2003). Comfort, cleanliness and convenience the social organization of normality, Berg, Oxford.

Silverstone, R., Hirsch E. and Morley, D. (1992) Information and communication technologies and the moral economy of the household, in R. Silverstone and E. Hirsch (eds.): Consuming Technologies: Media and Information in Domestic Spaces, Routledge, London, pp. 15-31. Skill, K. (2008) (Re)Creating ecological action space: householders' activities for sustainable development in Sweden, Diss. Linköpings universitet, Linköping.

SOU 2008:25 (Swedish Government Official Reports) (2008) Ett energieffektivare Sverige. Delbetänkande av Energieffektiviseringsutredningen, Fritze, Stockholm.

Stagl, S. (2006) Multicritera evaluation and public participation: the case of UK energy policy. Land use policy, 23, 53-62.

Statistics Sweden (2010). Yearbook of Housing and Building Statistics 2010: Official Statistics of Sweden, Statistics Sweden, Örebro.

Stevenson, F. and Leaman, A. (2010) Evaluating housing performance in relation to human behaviour: new challenges. Building Research and Information, 38(5), 437-441.

Stewart, J. and Williams R. (2005) The wrong trousers? Beyond the design fallacy: Social learning and the user, reprinted, in Howcroft, D. and Trauth E. (eds.): Handbook of Critical Information Systems Research: theory and application, Edward Elgar, Cheltenham, pp. 195-221. Summerton, J. (1994) Introductory Essay: The Systems Approach to Technical Change, in Summerton, J. (ed.): Changing Large Technical Systems, Westview Press, Boulder, pp. 1-24. Swedish Environmental Protection Agency (Naturvårdsverket) (2010) Effekter av investeringsprogrammen LIP och Klimp: redovisning till regeringen april 2010,

Naturvårdsverket, Stockholm.

Swedish national board of housing, building and planning (Boverket) (2002) Hushållning med kallt och varmt tappvatten: Individuell mätning och temperaturstyrning, Boverket, Karlskrona. Sørensen, K. H. (1996) Learning technology, constructing culture: socio-technical change as social learning. STS Working Paper no. 18/96, Centre for Technology and Society, University of Trondheim, Trondheim.

Sørensen, K. H. and Williams R. (2002) Shaping Technology, Guiding Policy: Concepts, Spaces and Tools, Edward Elgar, Cheltenham, UK and Northampton, MA, USA.

Vidén, S. and Botta, M. (n.a.) Bostadsförnyelse och miljöåtgärder med stöd av lokala investeringsprogram Hållbar utveckling i 50-60-70-talens bostadsområden, The Royal Institute of Technology, Stockholm. 
Wilhite, H., Shove, E., Lutzenhiser L. and Kempton, W. (2000) Twenty years of energy demand management: we know more about individual behaviour, but how much do we really know about demand, in Proceedings of the American Council for an Energy Efficient Economy, ACEEE, Washington DC.

Wilhite, H., Nakagami, H., Masuda, T., Yamaga, Y. and Haneda, H. (1996) A cross-cultural analysis of household energy use behaviour. Energy Policy 24(9), 795-803.

Williams, R., Slack, R. and Stewart, J. (2000) Social Learning in Multimedia: Final Report to European Commission, DGXII, Research Centre for Social Sciences: Edinburgh University, Edinburgh.

Williams, R., Stewart, J. and Slack, R. (2005) Social Learning and Technological Innovation: Experimenting with Information and Communication Technologies, Edward Elgar, Cheltenham, UK and Northampton, MA, USA.

Yin, R.K. (1994) Case study research: design and methods. (2 ed.) Sage Publications, Thousand Oaks. 


\section{Endnotes}

1. Hammarby Sjöstad in Stockholm and Västra Hamnen in Malmö received most the funding in the new development category and have also attracted more national and international attention. 2. In 2010, a post doctoral research fellow and a research assistant spent one month trying to make reliable calculations and comparisons but failed due to unreliable data.

3. Proper assessments and evaluations are also lacking of the new developments receiving government funding, namely, Hammarby Sjöstad and Västra Hamnen (Green 2006).

4. A typical interview with a technician would result in 15 pages of transcribed text.

5. A typical household interview would result in 10 transcribed pages.

6. An overview of background information about the tenants can be found in table 2, but has not been used in the analyses.

7. Privacy issues were discussed with the interviewees before the formal interviews started, and interviewees gave their informed consent. During the observations, informed consent was only sought from and granted by the professional who was shadowed. However, since only general descriptions of high-frequency situations involving residents are discussed here, privacy is not an issue. 
Table 1. Technical measures undertaken in the Ringdansen renovation (Vidén and Botta, 2006)

\begin{tabular}{|c|c|c|c|}
\hline Type & $\begin{array}{l}\text { Cost (EUR } \\
\text { thousands) }\end{array}$ & Specifications & Year \\
\hline \multirow[t]{2}{*}{ Energy systems } & 10250 & $\begin{array}{l}\text { Geothermal heating } \\
\text { (providing } 420 \mathrm{~kW} \\
\text { of heating to } \\
\text { supplement the } \\
\text { district system) }\end{array}$ & 1999-2004 \\
\hline & & $\begin{array}{l}\text { Heat exchangers in } \\
\text { the ventilation } \\
\text { systems }\end{array}$ & \\
\hline \multirow[t]{3}{*}{ Control systems } & 1020 & $\begin{array}{l}\text { Smart metering and } \\
\text { billing system }\end{array}$ & 1999-2004 \\
\hline & & $\begin{array}{l}\text { Motion detectors } \\
\text { for lighting }\end{array}$ & \\
\hline & & $\begin{array}{l}\text { Entrance control } \\
\text { tags and } \\
\text { surveillance } \\
\text { cameras }\end{array}$ & \\
\hline \multirow[t]{2}{*}{ Construction } & 36175 & $\begin{array}{l}\text { Extra insulation in } \\
\text { the external walls }\end{array}$ & 1999-2004 \\
\hline & & $\begin{array}{l}\text { New rooftops with } \\
\text { extra insulation }\end{array}$ & \\
\hline
\end{tabular}




\begin{tabular}{|l|l|l|l|}
\hline & & $\begin{array}{l}\text { Improved U-values } \\
\text { for windows and } \\
\text { balcony doors } \\
\text { (different measures } \\
\text { were used to } \\
\text { achieve this) }\end{array}$ & \\
\hline Recycling and & 1063 & & \\
waste & & $\begin{array}{l}\text { Six new recycling } \\
\text { stations (for 11 } \\
\text { different waste } \\
\text { fractions) }\end{array}$ & $1999-2004$ \\
\hline Water and sewage & 5277 & & \\
\hline Local environment & 8800 & $\begin{array}{l}\text { Water- and energy- } \\
\text { saving shared } \\
\text { laundry rooms }\end{array}$ & $1999-2004$ \\
\hline & & $\begin{array}{l}\text { Storm water } \\
\text { collection and reuse } \\
\text { (for non-domestic } \\
\text { purposes) }\end{array}$ & \\
\hline & & $\begin{array}{l}\text { More green areas } \\
\text { between buildings } \\
\text { and in the park } \\
\text { areas (hard surfaces } \\
\text { were converted to } \\
\text { grass) }\end{array}$ & \\
\hline & & $1999-2004$ & \\
\hline & & & \\
\hline
\end{tabular}




\begin{tabular}{|l|l|l|l|}
\hline User involvement 923 & $\begin{array}{l}\text { Individual and } \\
\text { group meetings and } \\
\text { feedback during and } \\
\text { after the renovation }\end{array}$ & $1998-2004$ \\
& & \\
\hline
\end{tabular}


Table 2. Results from the renovation of Ringdansen: energy and water consumption (Karlsson 2008)

\begin{tabular}{|l|l|l|l|}
\hline & $\begin{array}{l}\text { Before renovation (at } \\
\text { the time of the } \\
\text { application, 1997) }\end{array}$ & 2004 & $\begin{array}{l}\text { Estimated use } \\
\text { savings, } \\
2004(\%)\end{array}$ \\
\hline Total energy purchased & $37,601 \mathrm{MWh}$ & $18,259 \mathrm{MWh}$ & $51.4 \%$ \\
\hline - energy for heating & $29,238 \mathrm{MWh}$ & $13,817 \mathrm{MWh}$ & $52.7 \%$ \\
\hline - electricity & $8361 \mathrm{MWh}$ & $4441 \mathrm{MWh}^{-1}$ & $46.9 \%$ \\
\hline Cold water consumption & $252,530 \mathrm{~m}^{3}$ & $103,809 \mathrm{~m}^{3}$ & $59 \%$ \\
\hline
\end{tabular}


Table 3. Description of household interviewees.

\begin{tabular}{|c|c|c|c|c|c|}
\hline Household & $\begin{array}{l}\text { No. of family } \\
\text { members * }\end{array}$ & Country of birth & Occupation & $\begin{array}{l}\text { Estimated age } \\
\text { (years) }\end{array}$ & $\begin{array}{l}\text { Yearly household } \\
\text { income (EUR) }\end{array}$ \\
\hline 1 & $2 \mathrm{~A}(\mathrm{~F}, \mathrm{M}), 6 \mathrm{C}$ & Syria & $\begin{array}{l}\text { Unemployed (F) Self- } \\
\text { employed (M) }\end{array}$ & $30-40$ & 40000 \\
\hline 2 & $2 \mathrm{~A}(\mathrm{~F}, \mathrm{M}), 1 \mathrm{C}$ & $\begin{array}{l}\text { Sweden (F), Chile } \\
\text { (M) }\end{array}$ & e Student (F) Assembler (M) & $20-30$ & n.a. \\
\hline 3 & $1 \mathrm{~A}(\mathrm{~F})$ & Sweden & Teacher & $60-70$ & 36000 \\
\hline 4 & $2 \mathrm{~A}(\mathrm{~F}, \mathrm{M}), 3 \mathrm{C}$ & $\begin{array}{l}\text { Sweden (F), } \\
\text { Denmark (M) }\end{array}$ & $\begin{array}{l}\text { Care worker } \\
\text { (F) Unemployed (M) }\end{array}$ & $40-50$ & 60000 \\
\hline 5 & $1 \mathrm{~A}(\mathrm{~F}), 2 \mathrm{C}$ & Sweden & Student & $30-40$ & 19000 \\
\hline 6 & $1 \mathrm{~A}(\mathrm{~F})$ & Sweden & Hostess in a restaurant/student & $30-40$ & "varies" \\
\hline 7 & $2 \mathrm{~A}(\mathrm{~F}, \mathrm{M})$ & Finland & Pensioner (F and $\mathrm{M})$ & $60-70$ & n.a. \\
\hline 8 & $2 \mathrm{~A}(\mathrm{~F}, \mathrm{M}), 1 \mathrm{C}$ & $\begin{array}{l}\text { "Abroad" } \\
\text { (F) Sweden (M) }\end{array}$ & Unknown (F) Job agent (M) & $30-40$ & 25000 \\
\hline 9 & $2 \mathrm{~A}(\mathrm{~F}, \mathrm{M}), 1 \mathrm{C}$ & Turkey & $\begin{array}{l}\text { Disability pensioners ( } \mathrm{F} \text { and } \\
\mathrm{M})\end{array}$ & $60-70$ & "low pension" \\
\hline 10 & $2 \mathrm{~A}(\mathrm{~F}, \mathrm{M})$ & Turkey & $\begin{array}{l}\text { Disability pensioners ( } \mathrm{F} \text { and } \\
\mathrm{M})\end{array}$ & $60-70$ & "low" \\
\hline 11 & $2 \mathrm{~A}(\mathrm{~F}, \mathrm{M})$ & Sweden & Pensioner $(\mathrm{F}$ and $\mathrm{M})$ & $60-70$ & "pension" \\
\hline 12 & $2 \mathrm{~A}(\mathrm{~F}, \mathrm{M})$ & Germany & Doctor $(\mathrm{F}) \quad$ Engineer $(\mathrm{M})$ & $30-40$ & 68000 \\
\hline 13 & $2 \mathrm{~A}(\mathrm{~F}, \mathrm{~F}), 1 \mathrm{C}$ & Turkey & $\begin{array}{l}\text { Disability pensioner }(\mathrm{F}) \text { Pre- } \\
\text { school teacher }(\mathrm{F})\end{array}$ & $50-60$ and $20-30$ & 010,000 and "varies" \\
\hline 14 & $2 \mathrm{~A}(\mathrm{~F}, \mathrm{M}), 3 \mathrm{C}$ & Syria & 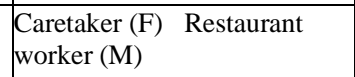 & $20-30$ & 25000 \\
\hline 15 & $2 \mathrm{~A}(\mathrm{~F}, \mathrm{M}), 2 \mathrm{C}$ & Syria & $\begin{array}{l}\text { Student (F) Self-employed } \\
\text { (M) }\end{array}$ & $20-30$ & 27000 \\
\hline 16 & $1 \mathrm{~A}(\mathrm{M})$ & Sweden & Consultant & $30-40$ & 21000 \\
\hline 17 & $2 \mathrm{~A}(\mathrm{~F}, \mathrm{M}) 2 \mathrm{C}$ & Bosnia & Manual worker $(\mathrm{F}$ and $\mathrm{M})$ & $40-50$ & 55000 \\
\hline 18 & $2 \mathrm{~A}(\mathrm{~F}, \mathrm{M}) 3 \mathrm{C}$ & Syria & Interpreter (F) Builder (M) & $30-40$ & n.a. \\
\hline 19 & $2 \mathrm{~A}(\mathrm{~F}, \mathrm{~F})$ & Sweden & Students & $20-30$ & n.a. \\
\hline
\end{tabular}

\footnotetext{
* $\mathrm{A}=$ adults, $\mathrm{C}=$ Children, $\mathrm{F}=$ Female, $\mathrm{M}=$ Male
} 